\title{
Essential Oil Composition of Rose Flowers from Karangpring Village Jember District Extracted by Distillation and Enfleurage
}

\author{
Komposisi Minyak Atsiri Bunga Mawar dari Desa Karangpring Kabupaten \\ Jember yang diekstrak melalui Distilasi dan Enfleurasi \\ Ika Oktavianawati ${ }^{1 *}$, Nanda Letisya ${ }^{1}$, Priscillia Citra $^{1}$, Dwi Purwita Utari ${ }^{1}$, I Nyoman Adi \\ Winata $^{1}$, Wuryanti Handayani ${ }^{1}$, Ari Satya Nugraha ${ }^{2}$ \\ ${ }^{1}$ Dept. Chemistry, Faculty of Mathematics and Natural Sciences, University of Jember \\ ${ }^{2}$ Faculty of Pharmacy, University of Jember \\ *E-mail: ika.fmipa@unej.ac.id
}

\begin{abstract}
Karangpring is one tourist destination villages in Jember district which is popular with beautiful large rose field areas. Therefore, this area grows to be a leading producer of rose flowers in Jember district. However, the bulky presence of these flowers made its price becomes lower in regular days. Local community only uses and sells these fresh flowers as the flower for funeral. The rose flower has a great potency to be explored as a source of rose essential oil production. To date, there is no previous research on studying rose flowers from Karangpring village for its potency on the essential oil production. In this research, rose flowers were subjected to be extracted of its essential oil using two extraction methods, distillation, and enfleurage. Hydrodistillation resulted two phases of distillates, above part formed a cloudy white phase as a normal essential oil extracted from plants, and the lower phase was an aqueous phase containing rose hydrosols. Both phases of these condensates were analyzed using GCMS. Data explained that above phase, with a yield oil of $0.07 \%$, only contains long-chain hydrocarbons such as $n$-nonadecane, $n$-heptadecane, 9-nonadecene, and eicosane, while the lower phase only contains 2-phenylethyl alcohol. On the other hand, enfleurage of fresh rose flowers resulted in $0.06 \%$ oil yield. GCMS analysis of this oil shows that 2-phenylethyl alcohol, eugenol, and phenylacetic acid are three major compounds which take more than $85 \%$ of total rose absolute. The results show that enfleurage is a better method for extracting rose oil in better quality than using the distillation method, in term of the variety of volatile components. Meanwhile, hydrodistillation is still benefiting from producing rose water that is qualified as an industrial additive agent for food and cosmetic productions or even a new potent of agromedicine products.
\end{abstract}

Keywords: rose, rose oil, rose water, rose absolute, distillation, enfleurage.

\section{INTRODUCTION}

Rose flower has an economic and social value in the world, especially the Indonesian community. Some communities regularly use the flower as cut roses for many special events, such as birthday and wedding parties, also for funeral and cemetery flowers. Karangpring village is a leading producer and supplier for rose flowers in Jember district (Derap Desa, 2010; Arifin, 2017b). Local communities in Karangpring village frequently use rose flowers only as formal flowers for cemetery and funeral aim. Some also produce healthy labeled juice from rose flowers, or even as rose candies, teas, and crackers (Arifin, 2017a). Others also use rose water in cooking as a natural coloring agent (Saati et al. 2011), flavoring agents on desserts and many meat dishes (Karizaki et al. 2016; Alalwan et al. 2017). However, another valuable product from rose flowers which attracts the attention of the world is the production of rose oil,known as rose otto, in flavor and fragrance industry (Kovats, 1987). Since rose oil is one of the most expensive essential oil in the world market today, we proposed the way on the diversification product of rose flower as essential oil production in this research (Agaoglu, 2000; Kovacheva et al. 2010).

The main flavor component on the scent of rose flowers are $\beta$-damascone and $\beta$ damascenone (Pal, 2013). Nevertheless, it is also known that characteristic odor of rose flowers came from 2-phenylethyl alcohol which being a principal component in rose water (Watanabe et al. 2001; Sakai et al. 2007; Sakai et al. 2008; Kumar et al. 2014; Gunes, 2005; Hirata et al. 2016). Previous researches explained that bioactive molecule of 2phenylethyl alcohol inside rose flowers is in 
the form of 2-phenylethyl $\beta$-D-glucopyranoside (Eikani et al. 2005; Watanabe et al. 2002). However, most publications only mention the finding on aglycon part of it, i.e. 2phenylethylalcohol. It was assumed that instead of the presence of $\beta$-glucosidase inside the plant (Watanabe et al. 2001; Sakai et al. 2008), applying various pretreatment and extraction methods could hydrolyze the glycoside as well to produce 2-phenylethyl alcohol.

Some efforts have been made to extract rose oil with higher quality, meaning that it has a high content of rose alcohol, but low or even free of ester, higher alkanes, and fat (Eikani et al. 2005). Various methods to extract rose oil are distillation (Najem et al. 2011; Hosni et al. 2010; Agarwal et al. 2005), solvent extraction (Rusanov et al. 2011; Watanabe et al. 2001; Kurkeuoglu and Baser, 2003), enfleurage (Yulianingsih et al. 2007), and supercritical $\mathrm{CO}_{2}$ (Reverchon et al. 1997). Kumar et al.(2016) have applied distillation of Damask rose flowers with saline water containing $75 \mathrm{~g}$ $\mathrm{NaCl} / \mathrm{kg}$ of rose flowers to increase about $42 \%$ higher of rose oil content compared to distillation in water only. But there is a special consideration on applying this method in a significant scale process due to the adverseeffect of salt on damaging steel apparatus in a longer period.

Most of all, the use of hydrodistillation in kinds of literature is quite widespread for extracting rose oil from fresh rose flowers. It has been known that hydrodistillation product market value is higher than other product from different extraction methods, by the fact that the total number of essential oil components in hydrodistillation is over (Pal 2013). Research by Karmous et al. (2004) mentioned that hydrodistillation has a drawback that the effect of boiling floral material and water at the same time could lead a light burned odor in the final product of essential oil. Since hydrodistillation is also quite easy and inexpensive, then this method became economical for essential oil production and suitable to be applied to the local community as a kind of home industry.

Enfleurage also becomes a popular extraction method to produce absolutely because it applies a low temperature for extraction. Hence, enfleurage prevents the hydrolysis of essential oil component during extraction that can be occurred at high temperature process, and creates an unpleasant odour because of the presence of acetic acid, dimethyl ketone, acetaldehyde, sulfides, ammonia and methanol (Soe'eib et al. 2016; Muchtar et al. 2013; Yulianingsih et al. 2007; Oktavianawati et al. 2017).

Various rose extracts depending on the way they were extracted, have their names. Rose oil is normally obtained from the upper phase of distillate from steam, steam-water, and hydrodistillation methods. Rose concrete is obtained by solvent extraction of rose flowers and has a smooth like semi-solid performance, while rose absolute is derived from rose flower extraction using ethanol as solvent. Rose water is collected from the lower phase of distillate which also contains a valuable oxygenated compound which is responsible for the great odor of rose flowers (Ulusoy et al. 2009).

To date, there was no previous investigation on exploring essential oil from rose flowers in Jember district. Then, this current paper will discuss the potency of rose essential oil production and compare the oil quality, in terms of GCM analysis data, because of applying different extraction methods.

\section{METHODS}

\section{Materials}

Fresh rose flowers were obtained from a rose farmer community, Sumber Mawar, in Karangpring village, Jember district, from May to July 2018. Rose plantsthat were used in this research has been identified by Lembaga Ilmu Pengetahuan Indonesia (Indonesian Institute of Sciences) Balai Konservasi Tumbuhan Kebun Raya Purwodadi as Rosa hybrida Hort.

\section{Extraction Procedures \\ Hydrodistillation}

The whole flower of roses was used in new conditions and extracted by hydrodistillation method using a Clevenger apparatus for 4 hours. The condensate formed two phases of distillate. The upper phase was collected as rose oil, while the lower phase was rose water. Rose oil was subjected to further analysis using GCMS. Rose water was extracted using diethyl ether to obtain rose concrete and then was run for GCMS analysis as well.

\section{Enfleurage}

Chasis $(50 \times 50 \times 7)$ was smeared with 500 grams of shortening (white butter). 200 grams of fresh rose flowers were placed on the top of fat from shortening for five days. The flowers were changed in every 24 hours and substituted with the new fresh one in a similar weight. After five days, the fat containing essential oil was extracted using alcohol in a ratio of $2: 1$. Then the mixture was kept in $0-5^{\circ} \mathrm{C}$ during 24 hours. Filtration of this mixture results inpomade and extrait. Extrait was evaporated for its 
alcohol content which then produced a rose absolute Rose absolute was also analyzed for its volatile content using GCMS.

\section{Identification of Volatile Components}

Volatile compounds of the essential oil extracts were analyzed by GCMS-QP2010S Shimadzu with Rtx 5 MS column (length $30 \mathrm{~m}$; ID $0.25 \mathrm{~m}$; film $0.25 \mathrm{um}$ ), Helium gas as a carrier, EI 70 Ev. Column oven temp. $70^{\circ} \mathrm{C}$, injector temp. $300^{\circ} \mathrm{C}$, pressure $12 \mathrm{kPa}$, total flow $27.3 \mathrm{~mL} / \mathrm{min}$, column flow $0.49 \mathrm{~mL} / \mathrm{min}$, ion source temp. $250^{\circ} \mathrm{C}$, interface temp. $305^{\circ} \mathrm{C}$, solvent cut time $3 \mathrm{~min}$, detector gain $+0.00 \mathrm{kV}$. MS table, start time $3.20 \mathrm{~min}$, end time $70 \mathrm{~min}$, scan speed 1250 , event time $0.50 \mathrm{sec}$. The constituents of the oils were identified based on their chromatogram and by comparing their mass spectral data with those from Wiley mass spectral database.

\section{RESULTS AND DISCUSSION}

Hydrodistillation is a kind of distillation method that boils the sample together with water at the same time. Water molecules will diffuse into plant tissues and carry out essential oil from oil glands to evaporate and condense. The oil will naturally be separated from the aqueous phase in the distillate. In this current research, the expected rose oil from hydrodistillation method was presented in the above phase of distillate and was separated from rose water to yield $0.07 \%$ oil. The performance of this rose oil was in semisolid form with a white transparent waxy look when it was cooled at $0-5^{\circ} \mathrm{C}$ or even at room temperature. However, the odor of this rose oil does not represent the fragrance of rose flowers.

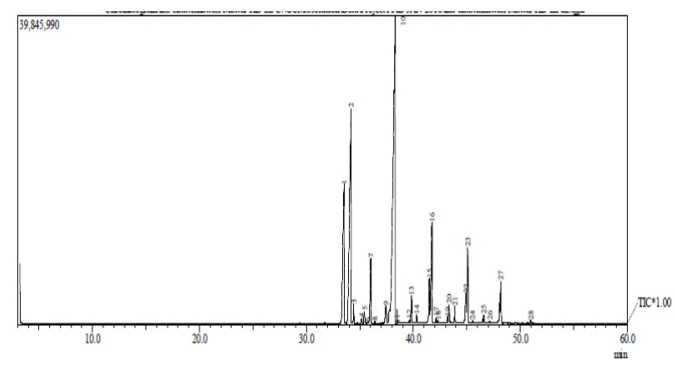

Figure 1. A chromatogram of rose oil from hydrodistillation method

Chromatogram of this rose oil can be seen in Figure 1, while the name list of those volatile compounds can be seen Table 1 . GCMS analysis showed that this rose oil only contains saturated and unsaturated aliphatic long chain hydrocarbon compounds, which is also known as stereoptanes, including $n$ nonadecane, $n$-heptadecane, 9-nonadecene, and eicosane. In this term, the form of rose oil as a wax-like material is possibly originating from the protective coatings of flowers which then makes the fat hardens and solidifies at room temperature (Sterrett 1962). The presence of this stearopten guarantees the durability of the scent (Dobreva et al. 2013).

Table 1. Chemical components in rose oil from Karangpring rose flowers

\begin{tabular}{cclr}
\hline No & $\begin{array}{c}\text { Retention } \\
\text { time }\end{array}$ & Compound Names & \% \\
\hline 1 & 33.509 & 9-nonadecene & 11.64 \\
2 & 34.167 & n-heptadecane & 26.52 \\
3 & 34.419 & 7-hexadecyne & 1.00 \\
4 & 35.426 & 1-octadecene & 0.59 \\
5 & 35.708 & Z-7-hexadecene & 0.09 \\
6 & 37.427 & 10-heneicosene & 1.59 \\
7 & 38.292 & $n$-nonadecane & 38.52 \\
8 & 38.476 & trans-1,4- & 0.23 \\
9 & 41.502 & dihydroxycyclohexane & \\
10 & 41.735 & eicosane & 4.43 \\
11 & 43.877 & stearaldehyde & 10.81 \\
12 & 45.546 & tridecanaldehyde & 1.40 \\
13 & 48.178 & $n$-hexatriacontane & 0.08 \\
14 & 50.982 & octadecyl chloride & 0.84 \\
\hline
\end{tabular}

This result research was relevant with the result of Moein et al. (2010) mentioning that Rosa damascena Mill. from South of Iran contains nonadecane, heneicosane, docosaneand 9-nonadecene in a total amount of $92.06 \%$ of the rose oil, while the rest comprises citronellol and germacrene-D. Our result showed a relative big different on the composition of rose essential oil from other research that also used hydrodistillation to extract rose oil. Babu et al. (2002) confirmed that damask rose oil from the western Himalayas contains rose alcohols (such as citronellol, nerol, and geraniol) up to $68.13 \%$ and long-chain hydrocarbons including nonadecane, heptadecane, 9-eicosene, and docosane for about $21.23 \%$ of the total oil. Dobreva et al. (2013) also enlighten the major volatile contents of three genotypes of oilbearing roses in Kazanluk are mostly consist of citronellol, geraniol, nerol and nonadecane. Phenylethyl alcohol, as a marker compound of rose flower, is also obtained from this research though, in trace quantity, $0.26-1.31 \%$ of total rose oil since it is a polar compound and more soluble in water. 


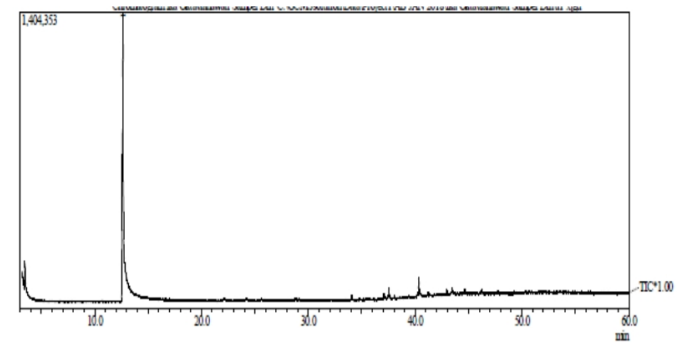

Figure 2. A chromatogram of rose water extracted with diethyl ether

It has been discussed before that upper phase of distillate, rose oil, contains only aliphatic hydrocarbons, while the lower phase only contains one polar and soluble compound in water, 2-phenylethyl alcohol (see chromatogram in Figure 2). This marker compound of rose oil was obtained when the lower distillate, as we knowas a hydrosol, was extracted using diethyl ether.Evaporation of diethyl ether resulted in a clear colorless liquid form of rose concrete. The odor of this extract represents the right fragrance of rose flowers with a pleasant odour. In our research, we do not find any other volatile compounds that could be extracted from this rose water, like other research which are conducted by Kurkeuoglu \& Baser (2003), Eikani et al (2005),Najem et al (2011), Agarwal et al (2003) and Babu et al (2002), using various solvents ofn-hexane, n-butylacetate,pentane, and dichloromethane, respectively, to isolate citronellol, geraniol, nerol, linalool and eugenol, instead of obtaining 2-phenylethyl alcohol.

This current research confirmed that hydrodistillation method is not a suitable method to extract the true rose oil since it does not contains any marker compound of rose flower, i.e 2-phenylethyl alcohol, or even any other highly polar and water-soluble compound, while the rose water contains. Thus, the distillation method could be chosen as the right method to produce valuable rose water or hydrosol because of a big content of 2-phenylethyl alcohol. This rose hydrosol was proven to be a safe material or additive in aromatherapy, cosmetics, andflavoring agents since it did not contain any lipophilic compounds that could interact and react with body tissues in topical application method (Adams et al. 2005).

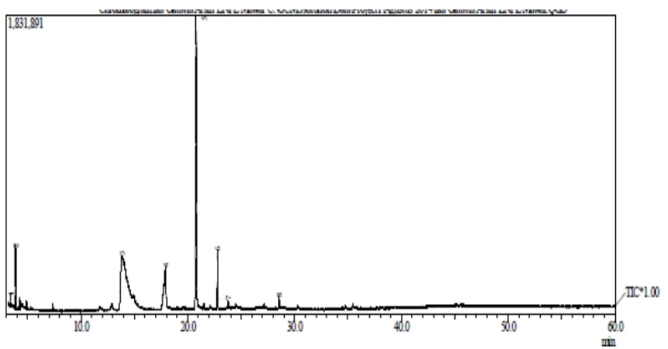

Figure 3. A chromatogram of rose absolute from five days enfleurage of fresh rose flowers.

Enfleurage method is chosen as an alternative method to extract essential oil from fresh rose flowers instead of hydrodistillation. Enfleurage applies cold fat as an adsorbent of volatile compounds deliberated by flowers. This research used a white butter or shortening as an adsorbent.

Table 2. Chemical components of rose absolute from enfleurage of fresh rose flowers

\begin{tabular}{|c|c|c|c|}
\hline No. & $\begin{array}{c}\text { Retention } \\
\text { time }\end{array}$ & Compound Names & $\%$ \\
\hline 1 & 3.448 & 2-propenoic acid & 0.96 \\
\hline 2 & 3.889 & glycolamide & 3.56 \\
\hline 3 & 13.857 & Phenylethyl alcohol & 40.48 \\
\hline 4 & 17.948 & phenylacetic acid & 12.91 \\
\hline 5 & 20.789 & eugenol & 35.16 \\
\hline 6 & 22.793 & $\beta$-caryophillene & 5.21 \\
\hline 7 & 23.778 & $\beta$-selinene & 0.63 \\
\hline 8 & 28.541 & 9-heptadecanone & 1.09 \\
\hline
\end{tabular}

Enfleurage of fresh rose flowers for five days resulted in a $0.06 \%$ oil yield with 'a light yellow liquid majorly containing 2-phenylethyl alcohol, eugenol and phenylacetic acid (Figure 3 and Table 2). Research of Yulianingsih et al. (2007) shows that seven days enfleurage on similar adsorbent, i.e white butter, of Middle Java red roses brings about $0.239 \%$ of rose absolute containing 2-phenylethyl alcohol, citronellol, geraniol, nerol and also eugenol. Although that we did not obtain any citronellol, geraniol and nerol in our rose oil, we found that it also contains phenylacetic acid. Although Watanabe et al. (2002) have explained that one way of biogenesis of 2-phenylethyl alcohol (route c) was from phenylacetic acid intermedietthe presence of phenylacetic acid in this research result was mostly predicted to became from the oxidation of 2-phenylethyl alcohol during enfluerage process. The 
presence of natural oxidators such as rose oxides and acids in enfleurage and defleurage process could influence the stability of 2phenylethyl alcohol. Moreover, possibility of the presence of microbes inside chassis and the fat, such as Acetobacter acetic, will oxidize 2phenylethyl alcohol into corresponding acid and aldehyde (Gandolfi et al. 2004).

Nevertheless, the rose absolute performance from enfleurage is quite impressive with a light yellow color oil and pleasant odor effect. There was no fat left from adsorbent to be the presence in the rose absolute, similar to another enfleurage we have done previously for Cananga odorata (Oktavianawati et al. 2017). This enfleuragealso has been applied practically on producing rose absolute to local community in Karangpring village, where those rose flowers came from. Moreover, enfleurage pomade or white butter residue has been extended to be the main material of soap making as well (Oktavianawati et al. 2018).

The use of hydrodistillation will result in a big problem on the extraction of the valuable oxygenated compound, 2-phenylethyl alcohol, since it can pass into solution in rose water for over than two-thirds of the oil, while the rose oil only contains less than one-third (Eikani et al. 2005). While the use of enfleurage on extracting high quality of rose absolute can be performed successfully. However, enfleurage and defleurage processes require a big effort on the preparation, extraction and purification of fragrance components from the adsorbent.

Overall, hydro distillation and enfleurage are compatible methods to obtain valuable fragrance compounds depend on our need, in the form of rose water or absolute. However, in order to be applied as home industry of rose oil from hydrodistillation is entirely not economical since it only produces low oil recovery yield from fresh rose flowers.

\section{CONCLUSION}

Bulky amount of rose flowers in Karangpring village can be a valuable natural resource on producing rose essential oi, and aromatic rose water depend on the extraction method to use. Rose oil is better extracted using enfleurage of fresh rose flowers than using hydrodistillation process by showing diverse compound types in it, from rose alcohols into stearoptenes. This rose absolute also has a more pleasant odor like the true fragrance of rose flowers than rose oil.
Beside, rose water showed a mature content of rose flower marker compound, 2-phenylethyl alcohol, making this aromatic water to be a precious candidate of flavor and aromatherapy agent obtaining from the distillation process.

\section{ACKNOWLEDGEMENT}

We would like to acknowledge DRPM and the University of Jember for providing research and community engagement grant in 2017. We also thankful to rose farmer community in Karangpring village, Jember district, for supplying the sample for research.

\section{REFERENCES}

Adams, T.B., Cohen, S.M., Doull, J., Feron, V.J., Goodman, J.I., Marnett, L.J., Munro, I.C., Portoghese, P.S., Smith, R.L., Waddell, W.J., Wagner, B.M. 2005. The FEMA GRAS Assessment of Phenylethyl Alcohol, Aldehyde, Acid, and Related Acetals and Esters Used as Flavor Ingredients. Food and Chemical Toxicology. 43: 1179-1206.

Agaoglu, Y.S. 2000. Rose Oil Industry and the Production of Oil Rose (Rosa damascene Mill.) in Turkey. Biotechnology and Biotechnological Equipment.14(2): 8-15.

Agarwal, S.G., Gupta, A., Kapahi, B.K., Baleshwar, Thappa, R.K., and Suri, O.P. 2003. Chemical Composition of Rose Water Volatiles. Journal of Essential Oil Research.17(3): 265-267.

Alalwan, T.A., Mandeel, Q.A., Al-Sarhani, L. 2017. Traditional Plant-Based Foods and Beverages in Bahrain. Journal of Ethnic Foods.4: 274-283.

Arifin, S. 2017. Sirup dan The menjadi Solusi Petani Bunga Mawar. Indikator Online. $22 \quad$ Agustus 2017. http://indikatoronline.com/2017/08/22/sirup -dan-teh-menjadi-solusi-petani-bungamawar/.

Arifin, S. 2017. Wisata Bunga Mawar di Jember. Indikator Online. 22 Agustus 2017. http://indikatoronline.com/2017/08/22/wisa ta-bunga-mawar-du-jember/.

Babu, K.G.D., Singh, B., Joshi, V.P., Singh, V. 2002. Essential Oil Composition of Damask Rose (Rosa damascena Mill.) Distilled Under Different Pressures and Temperatures. Flavour and Fragrance Journal.17: 136-140.

Derap Desa. 2010. Desa Karangpring Kecamatan Sukorambi. Mawar 
Menghampar di Penanggungan. Edisi XXIX. Maret 2010: 40.

Dobreva, A., Velcheva, A., Bardarov, V., Bardarov, K. 2013. Chemical Composition of Different Genotypes Oil-Bearing Roses. Bulgarian Journal of Agricultural Science.19(6): 1213-1218.

Eikani, M.H., Golmohammad, F., Rowshanzamir, S., Mirza, M. 2005. Recovery of Water-Soluble Constituents of Rose Oil Using Simultaneous DistillationExtraction. Flavour and Fragrance Journal.20: 555-558.

Gandolfi, R., Cavenago, K., Gualandris, R., Gago, J.V.S., Molinari, F. 2004. Production of 2-Phenylacetic Acid and Phenylacetaldehyde by Oxidation of 2Phenylethanol with Free Immobilized Cells of Acetobacter aceti. Process Biochemistry.39: 747-751.

Hirata, H., Ohnishi, T., Watanabe, N. 2016. Biosynthesis of Floral Scent 2Phenylethanol in Rose Flowers.Bioscience, Biotechnology, and Biochemistry.80(10): 1865-1873.

Hosni, K., Kerkenni, A., Medfei, W., Brahim, N.B., Sebei, H. 2010. Volatile Oil Constituents of Rosa canina L.: Quality as Affected by the Distillation Method. Organic Chemistry International.2010: 1-7.

Karizaki, V.M. 2016. Ethnic and Traditional Iranian Rice-Based Foods. Journal of Ethnic Foods.3: 124-134.

Karmous, T., Raynaud, C., Spoormans, K., Ayed, N., Talou, T. 2004. Aroma Profile Comparison of Different Tunisian Aromatic Waters. Journal of Essential Oil-Bearing Plants.7(1): 16-31.

Kovacheva, N., Rusanov, K., Atanassov, I. 2010. Industrial Cultivation of Oil Bearing Rose and Rose Oil Production in Bulgaria during $21^{\text {st }}$ Century, Directions and Challenges .Biotechnology and Biotechnological Equipment.24(2): 17931798.

Kovats, E. 1987. Composition of Essential oils. Part 7. Bulgarian Oil of Rose (Rosa damascena Mill.). Journal of Chromatography.406: 185-222.

Kumar, R., Sharma, S., Kaundal, M., Sood, S., Agnihotri, V.K. 2016. Variation in Essential Oil Content and Composition of Damask Rose (Rosa damascena Mill.) Flowers by Salt Application Under Mid Hills of the Western Himalayas. Journal of
Essential Oil Bearing Plants.19(2): 297306.

Kumar, R., Sharma, S., Sood, S., Agnihotri, V.K., Singh, V., Singh, B. 2014. Evaluation of Several Rosa damascena Varieties and Rosa bourboniana Accession for Essential Oil Content and Composition in Western Himalayas. Journal of Essential Oil Research.26(3): 147-152.

Kurkeuoglu, M., and Baser, K.H.C. 2003. Studies on Turkish Rose Concrete, Absolute, and Hydrosol. Chemistry of Natural Compounds.39(5): 457-464.

Moein, M., Karami, F., Tavallali, H., Ghasemi, Y. 2010. Composition of the Essential Oil of Rosa damascena Mill. from South of Iran. Iranian Journal of Pharmaceutical Sciences.6(1): 59-62.

Najem, W., Beyrouthy, M.E., Wakim, L.H, Neema, C., Ouaini, N. 2011. Essential Oil Composition of Rosa damascena Mill. From Different Localities in Lebanon.Acta Botanica Gallica.158(3): 365-373.

Oktavianawati, I., Susianti, S.A., Nurfadila, L., Winata, I.N.A. 2017. Enfleuration and Characterization of Essential Oil from Cananga odorata. Proceedings of the $2^{\text {nd }}$ International Conference on Life Sciences and Biotechnology. pp: 106.

Oktavianawati, I., Winata, I.N.A., Putra, S.D. 2018. Aplikasi Teknologi Pembuatan Sabun Mawar pada Kelompok Petani Mawar di Kabupaten Jember. Prosiding Seminar Nasional Inovasi dan Aplikasi Teknologi di Industri 2018. Tema B Abdimas: 391-393.

Pal, P.K. 2013. Evaluation, Genetic Diversity, Recent Development of Distillation Method, Chalengges and Opportunities of Rosa damascene: A Review.Journal of Essential Oil Bearing Plants. 16(1): 1-10.

Reverchon, E., Porta, G.D., Gorgoglione, D. 1997. Supercritical $\mathrm{CO}_{2}$ Extraction of Volatile Oil from Rose Concrete. Flavour and Fragrance Journal. 12: 37-41.

Rusanov, K.E., Kovacheva, N.M., Atanassov, I.I. 2011. Comparative GC/MS Analysis of Rose Flower and Distilled Oil Volatiles of the Oil Bearing Rose Rosa damascene. Biotechnology and Biotechnological Equipment.25(1): 2210-2216.

Saati, E.A., Theovilla, R.R.D., Simon, B.W., Aulanni'am. 2011. Optimalisasi Fungsi Pigmen Bunga Mawar Sortiran sebagai Zat Pewarna Alami dan Bioaktif pada Beberapa 
Produk Industri.Jurnal Teknik Industri.12(2): 133-140.

Sakai, M., Hirata, H., Sayama, H., Sekiguchi, K., Itano, H., Asai, T., Dohra, H., Hara, M., Watanabe, N. 2007. Production of 2Phenylethanol in Roses as the Dominant Floral Scent Compound from LPhenylalanine by Two Key Enzymes, a PLP-Dependent Decarboxylase and a Phenylacetaldehyde Reductase.Bioscience, Biotechnology, and Biochemistry.71(10): 2408-2419.

Sakai, M., Tomita, S., Hirata, H., Asai, T., Dohra, H., Hara, M., Watanabe, N. 2008. Purification and Characterization of $\beta$ Glucosidase Involved in the Emission of 2Phenylethanol from Rose Flowers.Bioscience, Biotechnology, and Biochemistry.72(1): 219-221.

Soe'eib, S., Asri, N.P., Saptati, A.S.D.N.H., Agustina, D.P. 2016. Enfleurage Essential Oil from Jasmine and Rose Using Cold Fat Adsorbent. Jurnal Ilmiah Widya Teknik. 15(1): 58-61.

Sterrett, F.S. 1962. The Nature of Essential Oils II. Chemical Constituents, Analysis. Journal of Chemical Education.39(5): 246251.

Ulusoy, S., Tinaz, G.B., Canbay, H.S. 2009. Tocopherol, Carotene, Phenolic Contents and Antibacterial Properties of Rose Essential Oil, Hydrosol and Absolute.Current Microbiology.59: 554558.

Watanabe, S., Hashimoto, I., Hayashi, K., Yagi, K., Asai, T., Knapp, H., Straubinger, M., Winterhalter, P., Watanabe, N. 2001. Isolation and Identification of 2Phenylethyl Disaccharide Glycosides and Mono Glycosides from Rose Flowers, and Their Potential Role in Scent Formation. Bioscience, Biotechnology, and Biochemistry.65(2): 442-445.

Watanabe, S., Hayashi, K., Yagi, K., Asai, T., MacTavish, H., Picone, J., Turnbull, C., Watanabe, N. 2002. Biogenesis of 2Phenylethanol in Rose Flowers: Incorporation of $\left[{ }^{2} \mathrm{H}_{8}\right]$ L-Phenylalanine into 2-Phenylethanol and its $\beta$-DGlucopyranoside during the Flower Opening of Rosa 'Hoh-Jun' and Rosa damanscena Mill. Bioscience, Biotechnology, and Biochemistry.66(5): 943-947.

Yulianingsih, Amiarsi, D., Sabari, S. 2007. Teknik Enfleurasi dalam Proses Pembuatan Minyak Mawar. Jurnal Hortikultura Balithi.17(4): 393-398. 
